\title{
The Role of Chitosan on Polyvinyl Chloride (PVC)-Glycerol Biocomposites for Blood Bag Application
}

\author{
Nabila Meutia Zahra ${ }^{1}$, Siswanto ${ }^{2}$ and Prihartini Widiyanti ${ }^{1,3^{*}}$ \\ ${ }^{1}$ Biomedical Engineering, Faculty of Science and Technology, Universitas Airlangga, Indonesia \\ ${ }^{2}$ Physics Departement, Faculty of Science and Technology, Universitas Airlangga, Indonesia \\ ${ }^{3}$ Institute of Tropical Disease, Universitas Airlangga, Indonesia \\ *Corresponding author: pwidiyanti@fst.unair.ac.id
}

Keywords: PVC, glycerol, chitosan, blood bag.

\begin{abstract}
The common blood bag in the market is made from a mixture of PVC and plasticizer. But the a number of occurrences where pockets of heavily polluted bacteria, blood requires blood bags which has the antibacterial characteristic. Antibacterial properties on the bags of blood can be raised with the addition of chitosan. This research aim is to know the influence of chitosan membrane biocomposite PVC-Glycerol against its biological and physical properties. Chitosan dissolved with a concentration of $0 \mathrm{wt} / \mathrm{v} \%$; wt $/ \mathrm{v} 0.5 \% ; 1 \mathrm{wt} / \mathrm{v} \% ; 1.5 \mathrm{v} / \mathrm{wt} \% \mathrm{wt} / \mathrm{v}$ and $2 \mathrm{wt} / \mathrm{v} \%$ mixed with glycerol with a 1:1 ratio. Then the mixture was mixed with PVC solution $15 \%$ and formed into a membrane by using the glass plates. Furthermore, the membranes are characterized using tensile test, hemolytic test, and antibacterial test. The physical characteristics of the tensile test indicate that the elongation percentage was $2.22-96.43 \%$ and tensile strength was 3.6-8 MPa. The test result of the hemolytic test and antibacterial test showed that biocomposite membrane of PVC-Glycerol-Chitosan are hemocompatible because it has a hemolysis percentage $\leq 5 \%$, while antibacterial test results showed that the membrane has a weak anti-bacterial due to bacterial inhibition zone diameter $\leq 5 \mathrm{~mm}$. Based on the characterization result, biocomposite membrane of PVC- Glycerol-Chitosan can be used for blood bag candidate.
\end{abstract}

\section{Introduction}

Blood transfusion is an important component in clinical area nowadays. The high demand for blood transfusion was in line with the high demand for the blood bag. In Surabaya, Indonesia, the stock of whole fresh blood and blood platelets were only 109 bags, while the normal amount of stored blood should be 300 units at minimal The number of blood needs in Indonesia around 5,1 blood bags per year ( $2 \%$ of Indonesia population), while the production of blood and its components on the remaining 4,1 million bags [1]. There is evidence of sepsis associated with the transfusion of bacterially contaminated blood components [2]. Clinical sepsis would be expected in at least 1 in 10 to 2 in 5 contaminated transfusions (200 to 1,600 cases). National passive-reporting studies from the United States, the United Kingdom, and France suggest that one-fifth to onethird would result in death (40 to 533 deaths per year) [3]. This translates to a risk of death from a transfusion of a bacterially contaminated platelet unit of between 1 in 7,500 and 1 in 100,000 [4]. (Staphylococcus strain and the variety of gram negative organisms are related with reported death in some cases. Bacterial cultures of whole blood or red cells, however, have shown a much higher incidence of bacterial contamination (2 to 4 per 1,000 units) [5].

The most adapted research works which perform anti-bacterial is the research conducted by Mohan et al, 2014. [6]. The research by Mohan is demonstrated that combining peptides would drive to achieved a broad-spectrum antimicrobial activity, increased microbicidal activity in terms of fold reduction of bacteria, lower MIC of the cocktail AMPs, and much more rapid time-kill kinetics. But there is no study about the investigation of antibacteria task in blood bag which has already performed previously. Our research which focused on the role of chitosan, especially from 
the its antibacteria capability would be very beneficial for biomedical engineering in blood bag clinical aplication.

The defect of blood bag could be a contamination of its raw materials. It defected the blood in the side the bag and made it failed to be transfused. In 2011, the Indonesian Red Cross in East Java, Indonesia was found 4 contaminated blood bags [1]. Besides that, another Red Cross from Madiun District in 2015 exterminated around 1000 blood bags due to infeasibility. The blood from the donor was reactive and contaminated with bacteria. The bacteria and the physical properties of the blood bags were the main factors of that contamination. The head of the blood transfusion in Indonesian Red Cross in Bandar Lampung District, Aditya M. Biomed also said that around 35000 blood bags received every month in there, $5 \%$ of them were contaminated.

The blood bag must have characteristics, like transparent, flexible, unbreakable in small radius bending, heat-tolerant while flowed with steam in the sterilization process, unbreakable while centrifuged, easy-handling and economical [2]. The blood bag on the market nowadays was made from polyvinyl chloride (PVC) with the mixture of plasticizer. Interestingly, more recent passive reporting studies of bacterially contaminated red cells from

The previous studies about the modification of the synthesis of blood bag were performed by Haryono [3]. The visual result of this study was that addition of compatibilizer which was the reaction product of PVC, maleic anhydrate, and benzoyl peroxide affected the product performance. The tensile strength result analysis showed that the addition of $10-30 \%$ filler on PVC was not significantly different. But on the addition of 40-50\% filler, the effect of compatibilizer took effect. The thermal property result analysis with thermo-gravimeter showed that the lost weight and the degradation temperature was comparable with the filler percentage added to the PVC matrix. The biocomposites had met the characteristics of the suitable blood bag which was flexible and heattolerant while flowed with steam in the sterilization process. But, there was a lot of incidents in which the blood bag was contaminated with bacteria so that it is needed to have the antibacterial blood bag [3].

The antibacterial property was aimed to minimize the spread of the bacteria to decrease the disease caused by the bacteria. The resulted antibacterial property was expected to harmonize with the PVC-glycerol biocomposites blood bag in order to maintain the original blood bag properties.

Nowadays, the blood bad with antibacterial property is really required because the blood transfusion is really important. With this new innovation, the damage of blood due to the bacterial contamination could be reduced. One of the problems solving to this condition is by adding chitosan. The addition of chitosan on the blood bag is aimed to give antibacterial property on the blood bag. This study would modify the blood bag based on PVC with the addition of chitosan to increase its antibacterial property. The addition of the chitosan was intended to give antimicrobial property and chitosan also has good hemocompatibility [4]. Related to the aforementioned information, several testing is needed to be conducted to observe the characteristics of the biocomposites, such as functional group test, mechanical test, hemolysis test and bacterial response. The functional group analysis of the blood bag was performed with Fourier- Transformed Infra-Red (FTIR). The mechanical strength of the blood bag was obtained through a tensile strength test using autograph. The blood bag material has tested the response towards the bacteria through the antibacterial test to know the effect of chitosan as an antimicrobial agent. The hemolysis test was performed to know the blood interaction with blood bag material, especially the blood cell response to the material.

\section{Materials and Methods}

\section{The synthesis of PVC-Glycerol with the Addition of Chitosan Variation}

The synthesis of PVC-glycerol biocomposites with the addition of chitosan was started with the making of PVC solution $15 \%$ with THF solvent. The chitosan solution was made with an acetic acid solvent with the concentration variation of $0.5 \mathrm{wt} / \mathrm{v} \%, 1 \mathrm{wt} / \mathrm{v} \%$ dan $2 \mathrm{wt} / \mathrm{v} \%$. The synthesis of 
the biocomposites membrane of PVC-glycerol was done by mixing the chitosan solution and glycerol first with the ratio of 1:1. Then, the mixture was added to the PVC solution and stirred until homogeneous and rest for 24 hours at room temperature and closed environment. The biocomposites mixture was then molded into a flat glass that was already cleaned with $96 \%$ alcohol and rest for 12 hours until dry. Then, the membrane was taken off from the flat glass and was characterized by FTIR test, antibacterial test and hemolysis test [5].

\section{Functional Group Test}

The functional group test was performed using Fourier Transform Infrared (FTIR) for observing the microstructure of the sample. The spectral analysis of FTIR was performed by molding the sample into a pellet with the width of $1 \mathrm{~cm}$. the sample was then inserted into the FTIR tube and illuminated. The result of the illumination would give the specific graph which showed the functional group of the tested sample.

\section{The Tensile Strength Test}

The tensile strength test was one of strain-stress test aiming to observe the material strength through tensile force. This test was using autograph. The sample was molded into rectangular shape with the bigger size in both ends. The sample was placed in a holder and the force range and speed was measured. The load cell would increase slowly and then stopped when the sample was broken. The force and the strain were recorded. Those steps were repeated for the rest of the sample. The tensile strength was calculated manually from the result of every sample in this test.

\section{The Hemolysis Test}

The hemolysis test was performed using human blood that has been given the ethylenediaminetetraacetic acid potassium salt (EDTA) anticoagulant. The $50 \mu \mathrm{L}$ blood was dissolved using $5 \mathrm{~mL}$ of saline and incubated using a water bath at the temperature of $37^{\circ} \mathrm{C}$ for 30 minutes. Then, the blood sample was centrifuged for 1 minutes and the supernatant was collected to be observed its wavelength absorption using UV-Vis Spectrophotometer.

\section{The Antibacterial Test}

The antibacterial test was performed with first culturing the Escherichia coli bacteria colony for representing gram-positive bacteria and Staphylococcus aureus bacteria colony for representing the gram-negative bacteria on the agar media in the $4 \mathrm{~mm}$ petri dish. A hole was placed in the agar media with the bacteria colony for the place of the biocomposites membrane of PVC-glycerol with the addition of chitosan. Then, the sample was incubated for 24 hours. The presence of the ring around the sample showed the resistance of the biocomposites to the bacteria.

\section{Results}

\section{The Functional Group Analysis}

The functional group characterization of the PVC-glycerol biocomposites membrane sample with the addition of chitosan was analyzed by using FTIR. The initial materials, such as chitosan, PVC, and glycerol was tested first. The result was shown in Figure 1. To know the functional group of the synthesized materials and to prove that there was a new bond, the functional group characterization was performed as shown in Figure 2. 


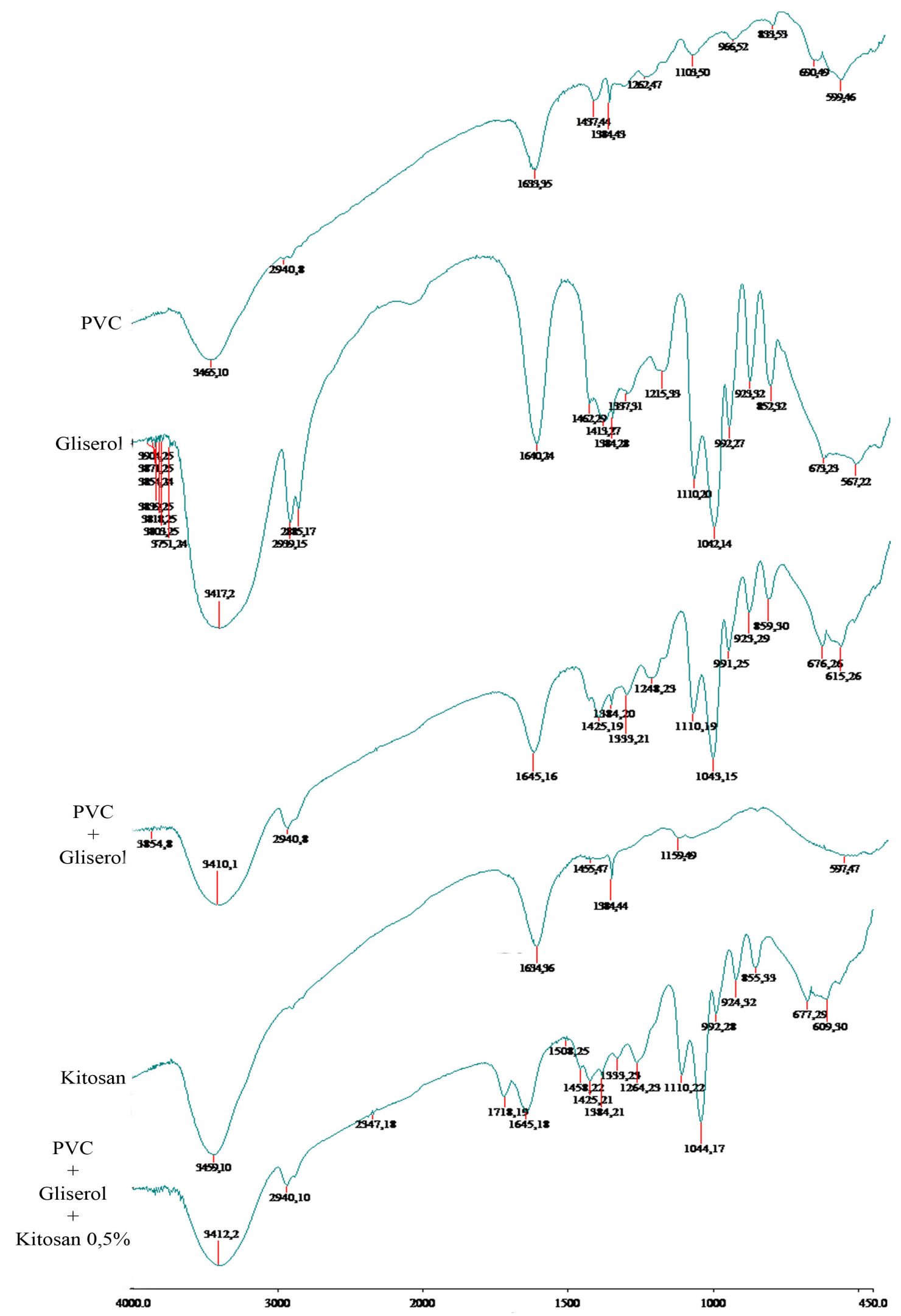

Fig 1. FTIR Spectra of PVC, Chitosan and Glycerol 


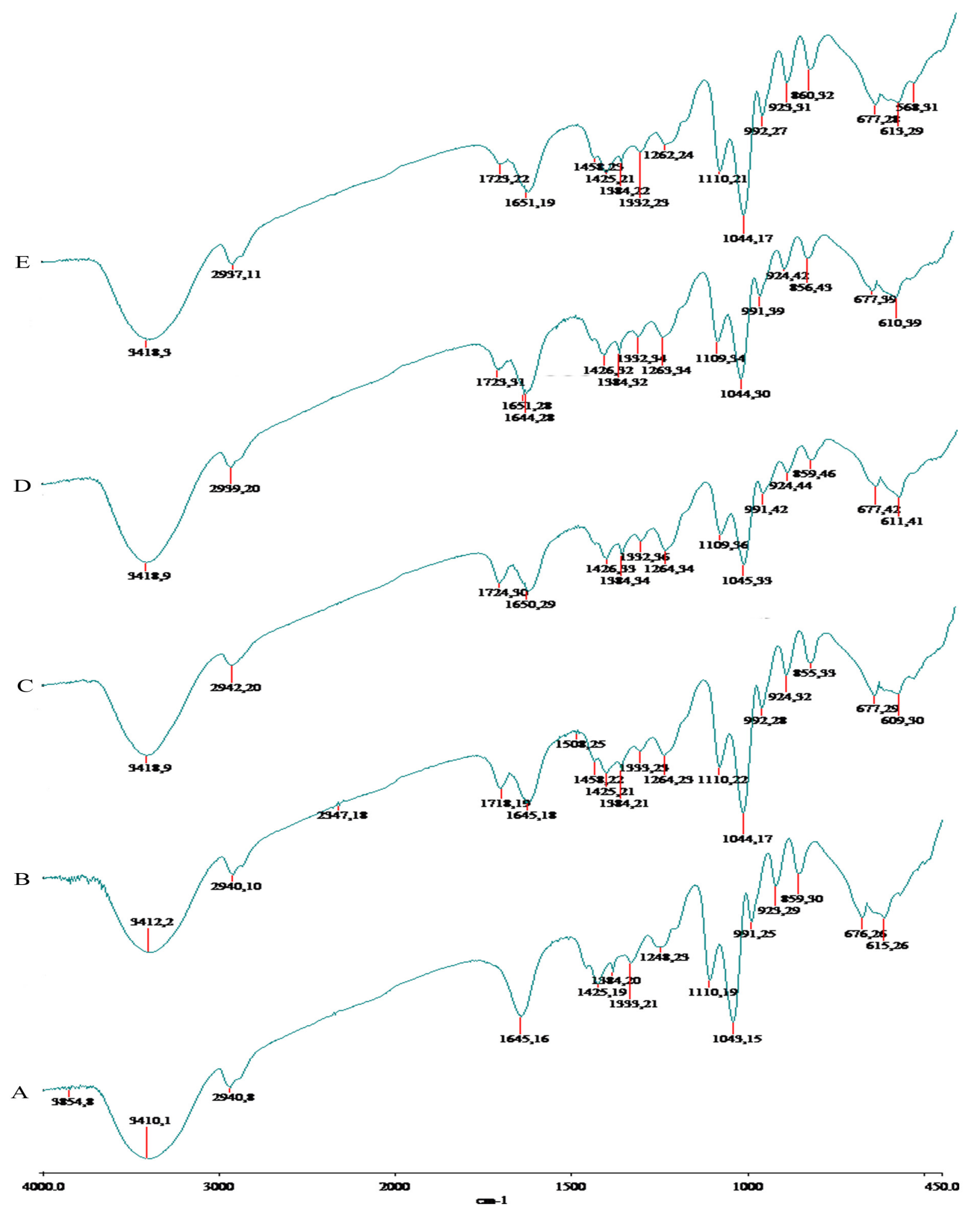

Fig 2. FTIR Spectra of PVC-Glycerol Biocomposites Membrane (A) with The Addition of Chitosan in Concentration of $0.5 \mathrm{wt} / \mathrm{v} \%$ (B), $1 \mathrm{wt} / \mathrm{v} \%(\mathrm{C}), 1.5 \mathrm{wt} / \mathrm{v} \%$ (D) dan $2 \mathrm{wt} / \mathrm{v} \%$ (E) 
Table 1. Functional Group Recapitulation

\begin{tabular}{|c|c|c|c|c|c|}
\hline \multicolumn{5}{|c|}{ Wave Number $\left(\mathrm{cm}^{-1}\right)$} & \multirow[b]{2}{*}{$\begin{array}{c}\text { Functinal } \\
\text { Group }\end{array}$} \\
\hline PVC & Glycerol & Chitosan & $\begin{array}{c}\text { PVC- } \\
\text { Glycerol } \\
\end{array}$ & $\begin{array}{l}\text { PVC-Glycerol- } \\
\text { Chitosan }\end{array}$ & \\
\hline 2940 & 2939 & - & 2940 & 2940 & $\mathrm{C}-\mathrm{H}$ \\
\hline 1437 & 1413 & - & 1425 & 1425 & $\mathrm{CH}_{2}$ \\
\hline 690 & - & - & 676 & 677 & $\mathrm{C}-\mathrm{Cl}$ \\
\hline - & 3417 & 3459 & 3410 & 3412 & $-\mathrm{OH}$ \\
\hline- & $1110-1042$ & 1159 & $1110-1045$ & $1110-1044$ & $\mathrm{C}-\mathrm{O}$ \\
\hline- & - & 1634 & - & 1645 & $\mathrm{~N}-\mathrm{H}$ \\
\hline
\end{tabular}

\section{The Tensile Strength Test}

The tensile strength analysis with autograph was aiming to observe the tensile strength of the PVC-Glycerol-Chitosan biocomposite membrane. This test was performed to know the maximum force of the sample and the break stress. The break stress is the tension when the sample is broken. The break stress was called tensile yield strength or tensile breaking.

Table 2. The Tensile Strength Test of PVC-Glycerol-Chitosan Biocomposites Membrane

\begin{tabular}{cccc}
\hline $\begin{array}{c}\text { Chitosan } \\
\text { Concentration } \\
(\%)\end{array}$ & $\begin{array}{c}\text { Max } \\
\text { Force (N) }\end{array}$ & $\begin{array}{c}\text { Break } \\
\text { Elongation (\%) }\end{array}$ & $\begin{array}{c}\text { Tensile Strength } \\
\text { (MPa) }\end{array}$ \\
\hline 0 & 5,65 & 96,43 & 3,6 \\
0,5 & 5,75 & 61,15 & 5,4 \\
1,0 & 8,35 & 26,75 & 8,0 \\
1,5 & 6,40 & 14,68 & 8,1 \\
2,0 & 9,60 & 2,22 & 12,2 \\
\hline
\end{tabular}

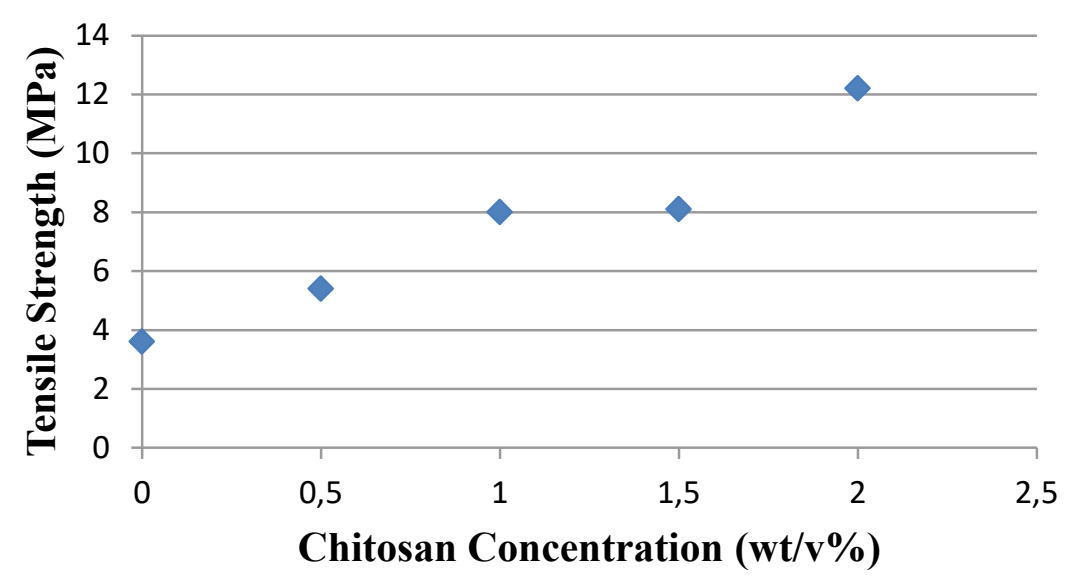

Fig 3. Tensile Strength (Mpa) Relation with Chitosan Concentration (\%)

\section{The Hemolysis Test}

The hemolysis test was aiming to know the blood response to the material when the blood is in contact with the material. The result of the hemolysis test was shown in Table 3. 
Table 3. Hemolysis Test Results

\begin{tabular}{cc}
\hline $\begin{array}{c}\text { Chitosan } \\
\text { Concentration (\%) }\end{array}$ & $\begin{array}{c}\text { Percentage of Hemolysis } \\
(\%)\end{array}$ \\
\hline 0 & 3,000 \\
1,0 & 1,700 \\
1,5 & 1,560 \\
2,0 & 0,920 \\
\hline
\end{tabular}

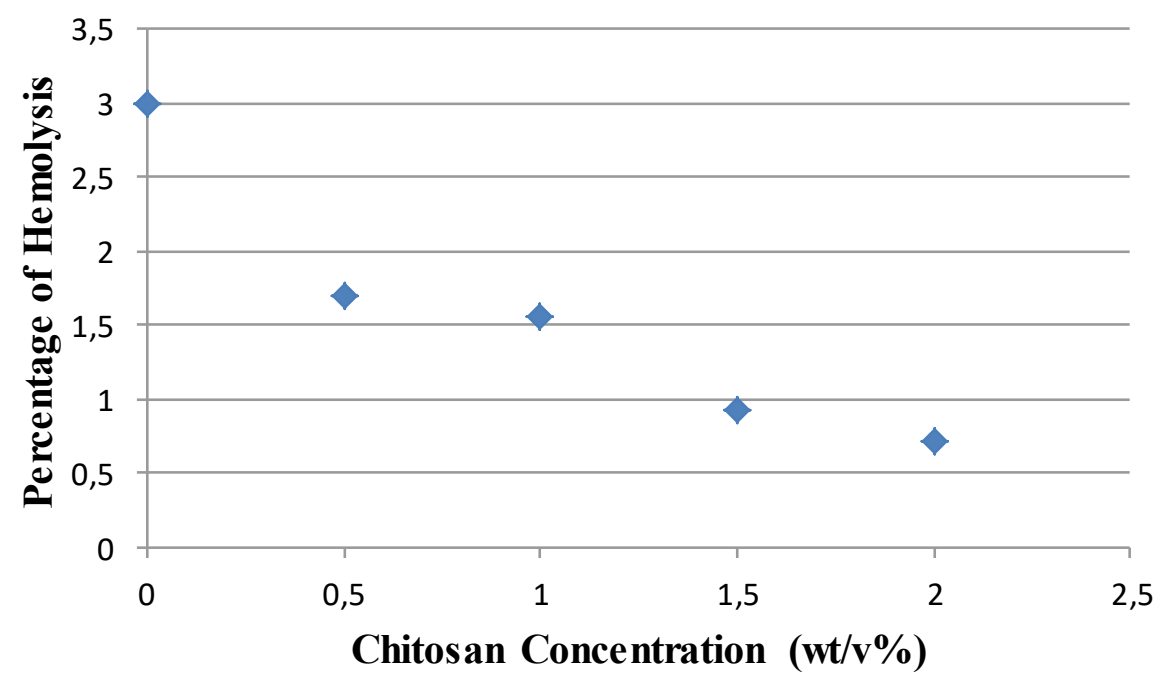

Fig 4. The Effect of Chitosan Concentration on Percentage of Hemolysis The Antibacterial Test

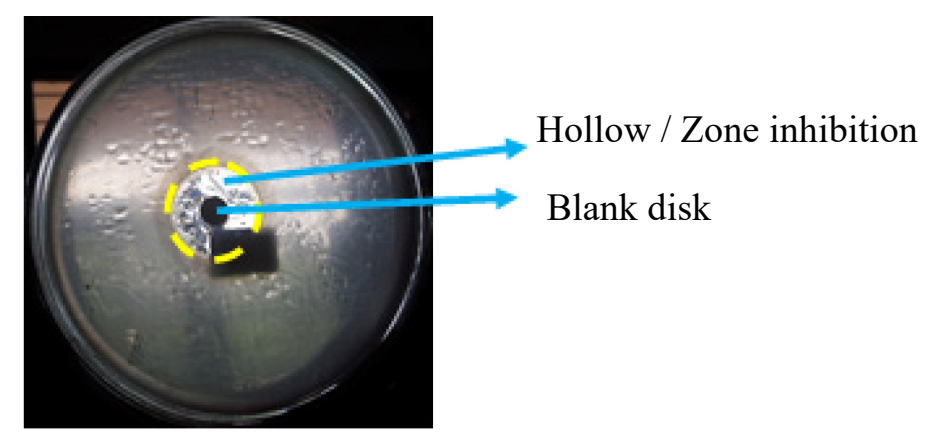

Fig 5. Antibacterial Test Results 


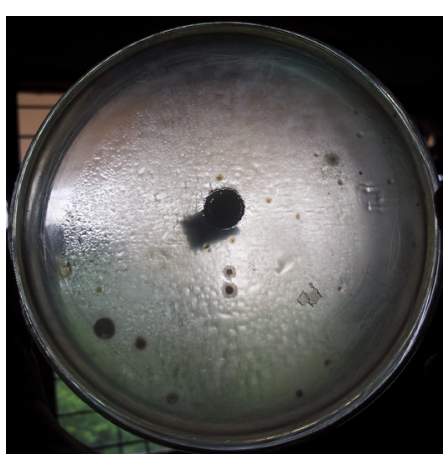

(a)

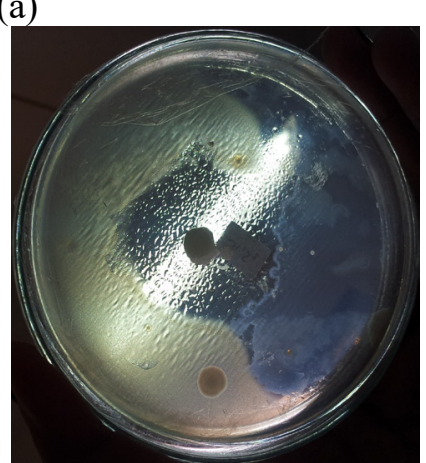

(d)

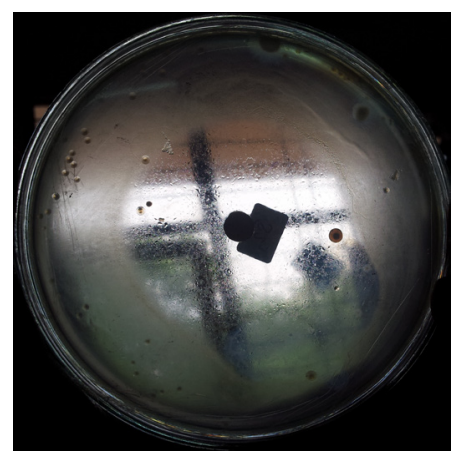

(b)

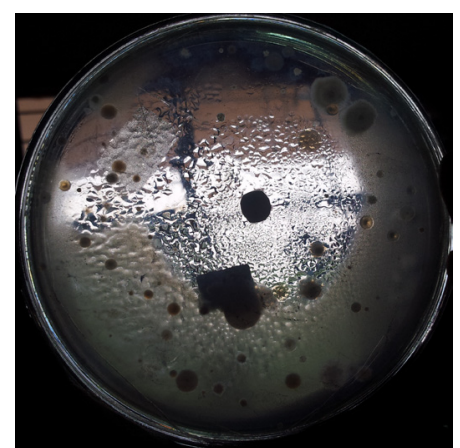

(c)

Fig 6. The Antibacterial Test of $S$. aureus on PVC-Glycerol-Chitosan Biocomposites Membrane with Chitosan Variation (a) $0 \mathrm{wt} / \mathrm{v} \%$; (b) $0.5 \mathrm{wt} / \mathrm{v} \%$; (c) $1 \mathrm{wt} / \mathrm{v} \%$; (d) $1.5 \mathrm{wt} / \mathrm{v} \%$ and (e) $2 \mathrm{wt} / \mathrm{v} \%$

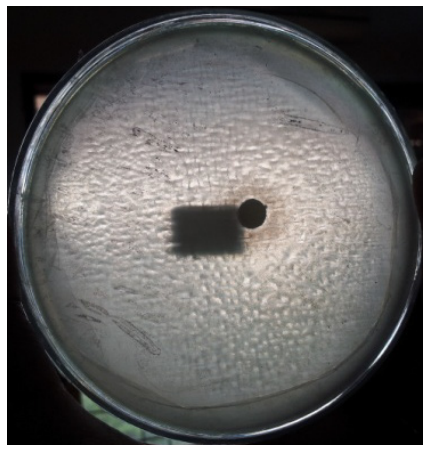

(a)

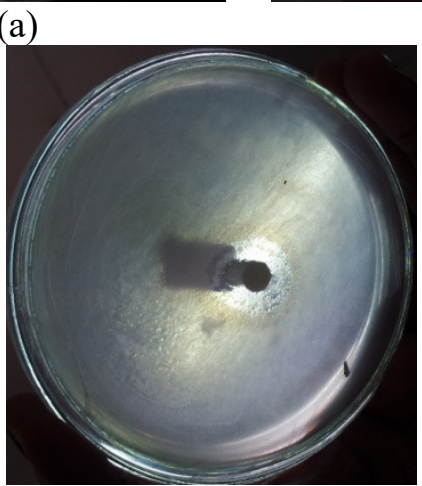

(d)

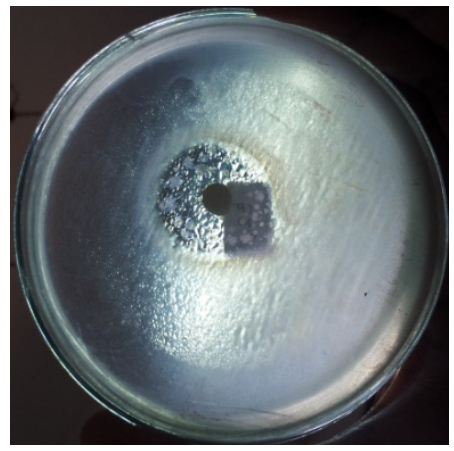

(b)

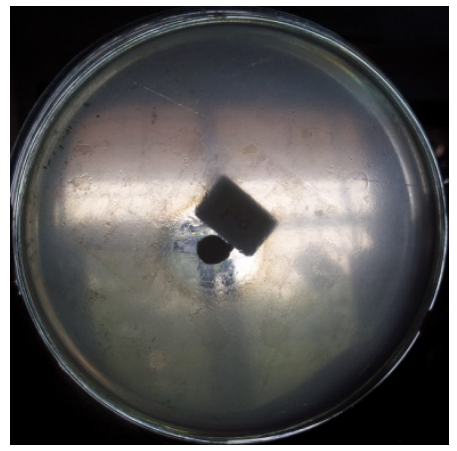

(c)

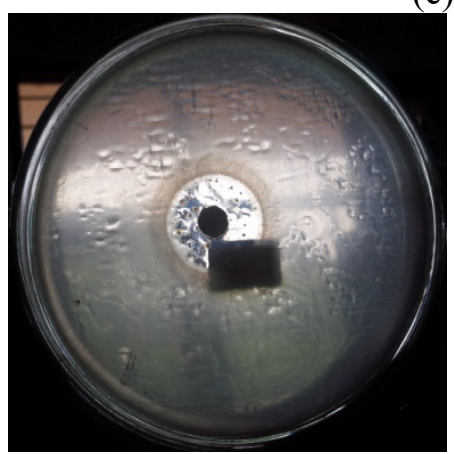

(e)

Fig 7. Antibacterial Test of B. subtilis on PVC-Glycerol-Chitosan Biocomposites Membrane with Chitosan Variation (a) $0 \mathrm{wt} / \mathrm{v} \%$; (b) $0.5 \mathrm{wt} / \mathrm{v} \%$; (c) $1 \mathrm{wt} / \mathrm{v} \%$; (d) $1.5 \mathrm{wt} / \mathrm{v} \%$ and (e) $2 \mathrm{wt} / \mathrm{v} \%$. 


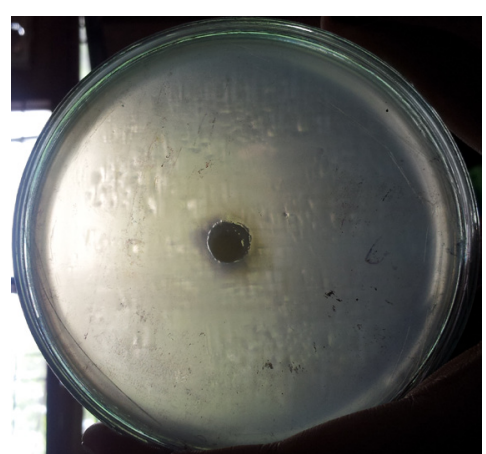

(a)

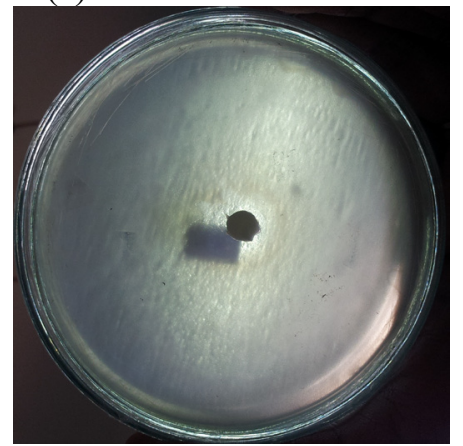

(d)

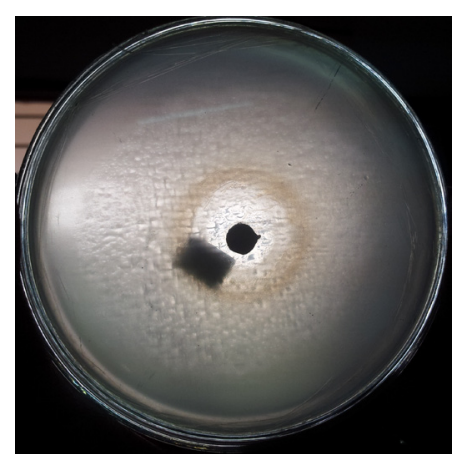

(b)

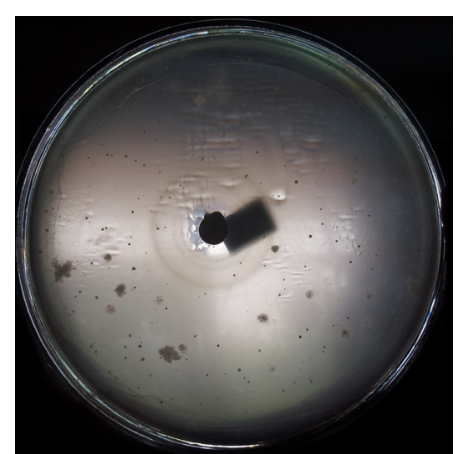

(c)

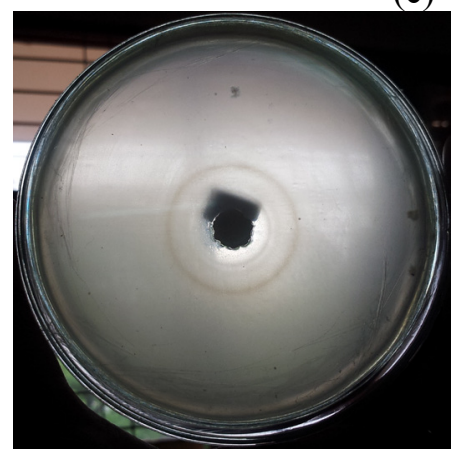

(e)

Fig 8. The test of PVC-Glycerol-Chitosan Biocomposites Membrane with Chitosan Variation (a) $0 \mathrm{wt} / \mathrm{v} \%$; (b) $0.5 \mathrm{wt} / \mathrm{v} \%$; (c) $1 \mathrm{wt} / \mathrm{v} \%$; (d) $1.5 \mathrm{wt} / \mathrm{v} \%$ and (e) $2 \mathrm{wt} / \mathrm{v} \%$

Table 4. Average bacterial inhibition zone diameter

\begin{tabular}{cccc}
\hline $\begin{array}{l}\text { Chitosan } \\
\text { Concentration } \\
(\%)\end{array}$ & \multicolumn{3}{l}{$\begin{array}{l}\text { Inhibition Zone Diameter Average } \\
(\mathbf{m m})\end{array}$} \\
\cline { 2 - 4 } & $\boldsymbol{B .}$ subtilis & S. aureus & E. coli \\
\hline 0 & 0.483 & 0.671 & 0.488 \\
0.5 & 1.950 & 4.897 & 1.032 \\
1,0 & 1.679 & 4.054 & 0.950 \\
1.5 & 1.454 & 3.740 & 0.867 \\
2,0 & 1.408 & 2.850 & 0.712 \\
\hline
\end{tabular}

\section{Discussions}

In this study, there were 5 samples, which were Sample A, B, C, D and E. Sample A was the PVC-glycerol membrane without the addition of chitosan. The Sample B until E was the PVCglycerol membrane with the addition of chitosan variation of $0.5 \%, 1 \%, 1.5 \%$, dan $2 \% \mathrm{wt} / \mathrm{v} \%$ respectively. The synthesized biocomposites membrane had the physical shape of white and thin with a smooth surface.

The functional group test results in FTIR of PVC, the absorption band on wavenumber of $1940 \mathrm{~cm}^{-1}$ showed the aliphatic C-H group. The typical absorption band of PCV appeared on the wavenumber of $1437 \mathrm{~cm}^{-1}$ which was the $\mathrm{CH} 2$ functional group. On the wavenumber of $690 \mathrm{~cm}^{-1}$, it showed the typical absorption peak for the stretched vibration of C-Cl. The FTIR spectra of glycerol provided information that on the wavenumber of $3417 \mathrm{~cm}^{-1}$, it showed the functional group of $\mathrm{OH}$. The absorption band on the wavenumber of $2939 \mathrm{~cm}^{-1}$ showed the functional group of C-H, while the absorption band on the wavenumber of $1413 \mathrm{~cm}^{-1}$ showed the functional group of $\mathrm{CH}_{2}$. The functional group of C-O was also shown on the absorption band at a wavenumber of 1110 $1042 \mathrm{~cm}^{-1}$. The FTIR spectra of PVC-glycerol biocomposites membrane showed the presence of $\mathrm{OH}$ group on the absorption band of $3401 \mathrm{~cm}^{-1}$ and the $\mathrm{C}-\mathrm{H}$ group on the absorption band of 1110 $1042 \mathrm{~cm}^{-1}$. This $\mathrm{OH}$ and $\mathrm{C}-\mathrm{H}$ group was originated from the glycerol, and the presence of 
absorption band on the wavenumber of $2490 \mathrm{~cm}^{-1}$ showed the aliphatic $\mathrm{C}-\mathrm{H}$ group and $676 \mathrm{~cm}^{-1}$ showed the stretched vibration of $\mathrm{C}-\mathrm{Cl}$ form the PVC. The FTIR spectra of chitosan (Figure 1), the absorption band on the wavenumber of $3459 \mathrm{~cm}^{-1}$ showed the stretched vibration of the -OH group. The typical absorption band of chitosan appeared on the wavenumber of $1634 \mathrm{~cm}^{-1}$ which showed the bent vibration of $\mathrm{N}-\mathrm{H}$ from amine group $\left(-\mathrm{NH}_{2}\right)$. The absorption band on the wavenumber of $1159.49 \mathrm{~cm}^{-1}$ showed the stretched vibration of $-\mathrm{C}-\mathrm{O}$ - group.

The absorption band of FTIR from PVC-Glycerol-Chitosan biocomposites membrane (0.5\%) could be seen in Figure 2. On that spectra, there was an absorption band which showed the functional group from PVC, glycerol, and chitosan. The functional group originated from PVC was shown with the presence of the absorption band on the wavenumber of 2940 and $667 \mathrm{~cm}^{-1}$ which were the aliphatic $\mathrm{C}-\mathrm{H}$ group and stretched vibration of $\mathrm{C}-\mathrm{Cl}$. The absorption band on the wavenumber of $1645 \mathrm{~cm}^{-1}$ showed the $\mathrm{N}-\mathrm{H}$ group from amine $\left(-\mathrm{NH}_{2}\right)$ owned by chitosan. The absorption band on the range of 1110-1042 $\mathrm{cm}^{-1}$ showed the $\mathrm{C}-\mathrm{H}$ group from glycerol appeared on the FTIR spectra of PVC-glycerol-chitosan biocomposites membrane all the complete result was presented in Table 1.

The mixture of PVC and chitosan allowed the partial interaction between chains or so-called dipole-dipole interaction between $\mathrm{C}-\mathrm{N}$ bond in the chitosan with the $\mathrm{C}-\mathrm{Cl}$ bond in the PVC [6]. This interaction could occur while the process of mixture occurred. It concluded that the mixture of PVC-chitosan was already obtained with several distributions between the chain of PVC and chitosan.

The result of the tensile strength test showed that PVC-glycerol biocomposites membrane without the addition of chitosan had the highest maximum force and tensile strength of $5.65 \mathrm{~N}$ and 3.6 MPa (shown in Table 2). The highest elongation at break was obtained by the PVC-glycerolchitosan with the chitosan concentration of $1.5 \%$. The result of the elongation percentage dropped with the increase of chitosan concentration because the bonding distance between molecules dropped too. The obtained elongation percentage was around $22-96.3 \%$. The decrease in the elongation due to the increase of chitosan concentration was suited with the aforementioned literature [7].

The higher the chitosan concentration, the higher the tensile strength of PVC-glycerol-chitosan biocomposites membrane, because the increase in the chitosan concentration would increase the number of the hydrogen bond. This increase resulted in a stronger and not-easy-to-break bond because it needed high energy to break the bond [8]. The formed hydrogen bond was the dipoledipole interaction between $\mathrm{C}-\mathrm{N}$ on the chitosan with the $\mathrm{C}-\mathrm{Cl}$ on the $\mathrm{PVC}$ as explained by Sobahi (2011) [6]. Thus, the increase of chitosan concentration would increase the tensile strength of PVCglycerol-chitosan biocomposites membrane, as shown in Figure 3.

The result of hemolysis test on Table 3 showed that all the samples had the hemolysis percentage less than 5\%. The highest hemolysis percentage was obtained by PVC-glycerol biocomposites membrane without the addition of chitosan, which was around 3.07\%. The PVC-glycerol-chitosan with chitosan concentration of $0.5 \mathrm{wt} / \mathrm{v} \%, 1 \mathrm{wt} / \mathrm{v} \%, 1.5 \mathrm{wt} / \mathrm{v} \%$ and $2 \mathrm{wt} / \mathrm{v} \%$ were non-hemolytic because they had the hemolysis percentage of $1.7 \%, 1.56 \%, 0.92 \%$ and $0.72 \%$ respectively as shown in Figure 4. Based on the previous studies, the hemolysis percentage less than 5\% showed that the PVC-glycerol biocomposites membrane with the addition of chitosan was hemocompatible [9]. The addition of chitosan could decrease the hemolytic properties of materials with the increase of its concentration because it complemented the surface of PVC membrane [10]. The chitosan would trigger the hemolysis through the surface induction which would trigger the electrostatic interaction [11]. The hydrophilic property of chitosan would decrease the contact area with the blood platelets because of the small friction between the material surface and the blood. In conclusion, it increased the hemocompatibility of the PVC-glycerol-chitosan biocomposites membrane and suitable for the application as a blood bag.

The antibacterial test was performed to know the ability of the PVC-glycerol-chitosan biocomposites membrane in inhibiting the bacteria growth. This test was performed by using 3 bacteria, which were $S$. aureus and B. subtilis representing the gram-positive bacteria and E. coli 
representing the gram-negative bacteria. When the samples were incubated in the petri dish with agar media and bacteria inside, the clear and hollow inhibition zone would take place around the blank disk that was immersed in the testing solution. The hollow zone was the place in which the bacteria growth was inhibited by the chitosan shown in Figure 5. The measurement of bacteria inhibition zone was performed by measuring the hollow diameter around the blank disk which was incubated on the agar media with $S$. aureus bacteria. The sample without the addition of chitosan had the inhibition zone around $0.671 \mathrm{~mm}$. The sample with the addition of chitosan had the inhibition zone diameter around $2.850 \mathrm{~mm}$ to $4.897 \mathrm{~mm}$.

Figure 7 showed the hollow around the blank disk that was incubated in the agar media with $B$. subtilis bacteria inside. The sample without the addition of chitosan had the average inhibition zone diameter of $0.483 \mathrm{~mm}$. the sample with the addition of chitosan had the inhibition zone diameter around $1.408 \mathrm{~mm}$ to $1.950 \mathrm{~mm}$. the inhibition zone was formed in the antibacterial test using E. coli shown in Figure 8. The sample without the addition of chitosan had the inhibition zone diameter around $0.712 \mathrm{~mm}$ to $1.032 \mathrm{~mm}$. the antibacterial test was performed three times replication for every bacteria type in every chitosan concentration variation so that the bacterial inhibition zone was obtained.

Table 4 showed the average of bacterial inhibition zone diameter which indicated the effect of chitosan concentration on the PVC-glycerol-chitosan biocomposites membrane on the diameter of inhibition zone of 3 bacteria, which were Staphylococcus aureus, Bacillus subtilis, and Escherichia coli. The data on Table 4 showed the decrease in the inhibition zone diameter with the increase in the chitosan concentration.

The biocomposites without the addition of chitosan had almost the same inhibition zone for 3 type of bacteria, which was $0.5 \mathrm{~mm}$. The inhibtion zone diameter on the $S$. aureus was the biggest one which was more than $2.5 \mathrm{~mm}$. The inhibition zone diameter on the B. subtilis was around $2 \mathrm{~mm}$ with the chitosan concentration of $0.5 \%$ and decreased until around $1.5 \mathrm{~mm}$ at the chitosan concentration of $2 \%$. The criteria of antibacterial power were categorized as weak if the inhibition zone was $5-10 \mathrm{~mm}$ and strong if the inhibition zone was $10-20 \mathrm{~mm}$ and very strong if the inhibition zone was more than $20 \mathrm{~mm}$ [12]. Based on this criteria, the antibacterial power of the PVCglycerol-chitosan biocomposites membrane on every chitosan concentration was weak because the inhibition zone diameter was less than $5 \mathrm{~mm}$.

The chitosan concentration has an important role in the antibacterial activity. The decrease in the antibacterial activity due to the chitosan concentration was related to the polymer chain structure. The low concentration had a better molecule distribution of the solvent with the number of low near inter-chain interaction. Thus, it maximized the charged part to interact with the other molecules [13]. The chitosan had antibacterial property because it had a positive charge in the amine group which interacted with a negative charge on the bacterial cell membrane and it resulted in the protein and microorganism intracellular substance leakage. The electrostatic interaction between positive charge of $\mathrm{R}-\mathrm{N}\left(\mathrm{CH}_{3}\right)_{3}{ }^{+}$with the positive charge on the bacterial cell membrane became the main cause of the cell lysis and as the main antibacterial mechanism [14-16].

The electrostatic interaction of positive charge $\mathrm{NH}^{3+}$ on the chitosan with the negative charge of the bacterial cell membrane was the main antibacterial mechanism. The thickness of peptidoglycan layer on the bacterial cell wall had the role of the structure stiffness with the chitosan interaction barrier [17]. This electrostatic interaction caused the formed interference becoming twice; first, with triggering the change on the wall membrane permeability property, so that it caused the instability on the internal osmosis and then inhibited the microorganism growth, and second, with the hydrolysis of peptidoglycan on the microorganism cell wall which caused the intracellular electrolyte leakage, such as potassium ion and the other constituent proteins with low molecular weight (as an example nucleic acid, glucose, and dehydrogenase lactate) [18]. The cell membrane which was interacted with the chitosan was detached from the cell wall and caused a vacuole-like structure under the wall [19]. The release of cell membrane caused the water and ion reflux and then the internal pressure decreased. 
The gram-positive bacteria cell wall was constituted by peptidoglycan and a small amount of protein, and the gram-negative bacterial cell wall was thinner but more complex and containing polysaccharide, protein, and lipid except peptidoglycan. The gram-negative bacteria cell wall had the outer membrane which was the outer surface of the cell wall [20]. The chitosan antibacterial mechanism for gram-positive bacteria was different the one for gram-negative bacteria [17]. The inhibition zone diameter on the $E$. coli had the smallest inhibition zone diameter because the antibacterial activity efficiency to the gram-negative bacteria, E. coli, was lower than that of the gram-positive bacteria, S. aureus and B. subtilis [18]. The E. coli inactivation mechanism by chitosan occurred through 2 simultaneous steps, which were the initial release of cell wall form its cell membrane and then the cell membrane breaking was taken place [20].

\section{Conclusion}

The physical characteristics of PVC-glycerol-chitosan biocomposites membrane that was shown from tensile strength test showed that the increased of the chitosan concentration was followed by the decrease of membrane elongation percentage from $96.43 \%$ to $2.22 \%$ and the increase of membrane tensile strength from 3.6 Mpa to $12.3 \mathrm{Mpa}$.

The biological characteristics of the PVC-glycerol-chitosan biocomposites membrane that was obtained from antibacterial test showed that the increase on the chitosan concentration was followed by the decrease of the bacterial inhibition zone for 3 different types of bacteria, on the B. subtilis was around $0.483-1.408 \mathrm{~mm}$, on the $\mathrm{S}$. aureus was around $0.671-2.850 \mathrm{~mm}$ and E. coli was around $0.488-0.712 \mathrm{~mm}$. The increase in the chitosan concentration also decreased the hemolysis percentage from $3.07 \%$ to $0.72 \%$.

\section{References}

[1] www.depkes.go.id/pdf.php?id=17071100002

[2] Haryono, Agus. Pengembangan Material Komposit PVC untuk Kemasan Kantong Darah. Puspiptek Serpong. Tangerang. 2013

[3] Kuehnert, M. J., V. R. Roth, N. R. Haley, K. R. Gregory, K. V. Elder, G. B. Schreiber, M. J. Arduino, S. C. Holt, L. A. Carson, S. N. Banerjee, and W. R. Jarvis. Transfusion-transmitted bacterial infection in the United States, 1998 through 2000. Transfusion 41 (2001)14931499.

[4] Ness, P. M., H. G. Braine, K. King, C. Barrasso, T. Kickler, A. Fuller, and N. Blades. Single donor platelets reduce the risk of septic transfusion reactions. Transfusion 41 (2001):857861.

[5] Brecher Me, Hay SN. Bacterial Contamination of Blood Components Clin Microbiol Rev. 18(1) (2005) 195-204.

[6] K.V.K. Mohan, S. Sainath Rao, Y. Gao, C.D. Atreya. Enhanced antimicrobial activity of peptide-cocktails against common bacterial contaminants of ex vivo stored platelets. Clinical Microbiology and Infection, European Society of Clinical Microbiology and Infectious Diseases,CMI 20 (2013) O39-O46 [7] Salleh, Eraricar et al. Structural Characterization and Physical Properties of Antimicrobial (AM) Starch-Based Films. World Academy of Science, Engineering and Technology (2009) 55.

[8] Utari, S. Pembuatan Bioplastik dari Campuran rumput laut Gracilaria coronopifolia dan Kitosan dengan Gliserol sebagai Plasticizer. Teknik Kimia. Bandar Lampung. 2008

[9] Hendershot., et al. ASTM Hemolysis. Washington: NAMSA. 2007

[10] Eldin MMS, Soliman EA, Hashem AI, Tamer TM. Chitosan modified membranes for wound dressing. J. Biomater, 22 (3) (2008) 158-168 
[11] Hirano et al. Wet Spun Chitosan-Collagen Fibers, Theis Chemical N- modification \& Blood Compatibility. Biomaterials 21 (2000) 997-1003

[12] Davis, Stout. Disc Plate Method of Microbiological Antibiotic Essay. Journal of Microbiology, 22(4)( 2004)

[13] Palermo, E F. Kuroda, K. Structural determinants of antimicrobial activity in polymers which mimic host defense peptides. Appl. Microbiol. Biotechnol., 87(2010) 1605-1615

[14] Rabea, EI. Badawy, M.E.-T. Stevens, C.V. Smagghe, G. Steurbaut, W. Chitosan as antimicrobial agent: applications and mode of action. Biomacromolecules, 4(2003)1457-1465

[15] Tripathi, S. Mehrotra, G. K. Dutta, P. K. Chitosan based antimicrobial films for food packaging applications. e-Polymers, 93(2008) 1-7

[16] Shahidi, F., Arachci, J, K. V., \&Jeon, Y, J. Food Application of Chitin and Chitosan. Trends in Food Science and Technology 10(2) (1999) . 37-51.

[17] Zheng, L.Y. and J.F. Zhu.Study on Antimicrobial Activity Of Chitosan With Different Molecular Weights. Carbohydrate Polimers. 2003

[18] Goy, Rejane C., Douglas de Britto, Odilio B. G. Assis. A Review of the Antimicrobial Activity of Chitosan. Polímeros: Ciência e Tecnologia.19(3) (2009) 241-247

[19] Raafat, D.; von Bargen, K.; Haas, A. \& Sahl, H. G. Appl. Environ. Microbiol., 74 (2008) 3764-3773

[20] Dutta, P. K. Tripathia, Shipra. Mehrotraa, G.K. Duttab, Joydeep. Perspectives for chitosan based antimicrobial films in food applications. Food Chemistry. 2009:114(4)1173-1182. doi:10.1016/j.foodchem.2008.11.047 